\title{
Питання психології
}

УДК 159.942

DOI: $10.33099 / 2617-6858-2019-52-2-112-1119$

Стасюк В. доктор психологічних наук, професор, кафедра морально - психологічного забезпечення діяльності військ (сил), Наџіональний університет оборони України імені Івана Черняховського ORCID ID 0000-0002-7943-8456

Лисенко Д. ад 'юнкт, кафедра морально - психологічного забезпечення діяльності військ (сил), Національний університет оборони України імені Івана Черняховського ORCID ID 0000-0003-4468-681X

\section{ЦІННІСНІ ОРІЄНТАЦІЇ В СТРУКТУРІ ДОВІРИ ВІЙСЬКОВОСЛУЖБОВЦІВ ДО КОМАНДИРА В ОСОБЛИВИХ УМОВАХ ДІЯЛЬНОСТІ}

\begin{abstract}
У статті розглянуто сочіально-психологічні особливості взаємозв'язку ціннісних орієнтацій та довіри особистості; проаналізовано взаємозв'язок між иіннісними орієнтаціями військовослужбовиів $і$ командирів та формуванням відносин довіри між ними; отримано індивідуальну ієрархію иінностей командира, якому довіряють.

Ключові слова: иінності; иіннісні орієнтації; термінальні иінності; інструментальні цінності; міжособистісні відносини; психологічне відношення; довіра; довірчі відносини.
\end{abstract}

Постановка проблеми. Важливу роль у формуванні відношення особистості до інших індивідів відіграють ціннісні орієнтації. Вони $є$ основою поглядів та переконань людини, формують установки, визначають спрямованість активності. В міжособистісних відносинах процес сприйняття партнера характеризується як оцінкою його властивостей у відповідності 3 власною системою цінностей, так i оцінкою схожості ціннісних орієнтацій (як ставлень особистості по відношенню до людських цінностей) загалом. Відповідність характеристик індивіда, що сприймається, "ціннісним психологічним стандартам" людини сприяе прояву привабливості, симпатії, взаєморозуміння, встановленню передумов для довірчих відносин. За таким умов набуває актуальності питання розкриття соціальнопсихологічних особливостей взаємозв'язку ціннісних орієнтацій та довіри особистості.

Аналіз останніх досліджень i публікацій. Проблема взаємозв'язку ціннісних орієнтацій та довіри особистості розкрита у працях низки зарубіжних вчених (Г. Джонс та Дж. Джорж, А.Б. Купрейченко, А.Ю. Алєксєєва, І.В. Балуцький та ін.). Українськими науковцями роль цінностей та ціннісних орієнтацій особистості досліджується у формуванні довіри при груповій взаємодії
(Г.В. Циганенко), довіри до реклами (А.В. Кульчицька), довіри до органів державної влади, громадських інститутів (Е.О. Гуськова). Разом 3 тим, мало висвітленим залишається питання ролі ціннісних орієнтацій у формуванні довірчих відносин в системі “підлеглий - керівник”.

Метою статті $\epsilon$ визначення соціально-психологічних особливостей взаємозв'язку між ціннісними орієнтаціями військовослужбовців і командирів та формуванням відносин довіри між ними.

Виклад основного матеріалу. Цінності відіграють важливу роль у житті людини. Вони впливають на характер та нахили особистості, визначають мотиви поведінки та діяльності, формують життєву позицію та допомагають фіксувати своє положення у світі. На думку американських психологів, цінності слугують керівними принципами в житті людини, стандартами при оцінці людей, дій та подій $[1,566]$. У філософському енциклопедичному словнику (за ред. В. Шинкарчука) зазначено, що цінності містять у собі спонукальний складник. Спрямовуючи індивідуальну та колективну діï, вони забезпечують граничні (останні) підстави для дії та діяльності. Наголошується, що цінності відіграють провідну роль в об'єднанні індивідів для спільних, колективних дій $[2,708]$. 


\section{Питання психології}

$\begin{array}{ccc}\text { Цінності } & \begin{array}{c}\text { виступають } \\ \text { формування }\end{array} \text { й } & \text { розвовоюю } \\ \text { ціннісних }\end{array}$ орієнтацій людини. Найбільш уживаним у психологічній літературі $є$ визначення ціннісних орієнтацій особистості через категорії “установка", “спрямованість”, “відношення". На думку М.М. Обозова, ціннісні орієнтації достатньо близькі за змістом 3 поняттям “атитюд” (соціальна установка) та фактично являють собою відношення, детерміноване потребами, мотивами, спрямованістю особистості [3, 16]. Вчений наголошує, що без індивідуальних потреб, мотивів, спрямованості, установок, ціннісних орієнтацій не може існувати психологічної (суб'єктивно-особистісної) включеності особистості в суспільні відносини. А.Б. Купрейченко зауважує, що ціннісні орієнтації є одним із важливих факторів, що детермінують формування відношення до іншої людини [4, 251]. Заслуговує на увагу думка В.П. Познякова, який вважає за доцільне до традиційної “тріади” компонентів, якими представлена структура психологічного відношення (когнітивного, емоційного та поведінкового), додати ще один ціннісний, що виявляється в оцінці об'єкта, виходячи з суб'єктивної ієрархії значущих для особистості цінностей $[5,8]$. Сукупність ціннісних орієнтацій визначає змістовний аспект спрямованості особистості і $€$ внутрішньою основою іiі ставлень до дійсності, а також поведінки. Ціннісні орієнтації істотно впливають на мотивацію поведінки, інтереси, стиль мислення особистості $[6,235]$.

Таким чином, ціннісні орієнтації важливий компонент структури особистості, що регулює iї мотивацію та поведінку. Система цінностей особистості є невід'ємною складовою як іï внутрішньо особистісних, так i міжособистісних відносин. У взаєминах між людьми ціннісні орієнтації відіграють роль підстав, стандартів при оцінці іншої людини: властивості об'єкта по взаємодії сприймаються крізь призму суб' єктивних цінностей.

Схожість в ціннісних орієнтаціях позитивно впливає на міжособистісні відносини. Низка науковців вказує на наявність взаємозв'язку між ступенем збігу у ціннісних орієнтаціях індивідів та формуванням довірчих взаємин між ними. На думку Л.Я. Гозмана, близькість ціннісних орієнтацій та поглядів позитивно впливають на розвиток атракції на початковому етапі розвитку відносин між людьми [7, 63-64]. M.M. Обозов зазначає, що наявність схожості в ціннісних орієнтаціях викликає більшу згоду між людьми у їх відношенні до світу, інших людей, самих себе [3, 73]. А.Ю. Алєксєєва зауважує, що одним 3 найбільш вагомих аспектів прояву довіри в міжособистісних відносинах $€$ почугтя впевненості по відношенню до цінностей іншої людини [8, с. 23]. Подібної думки дотримується I.B. Балуцький, який вважає спільність між людьми в ціннісно-смисловій сфері необхідною умовою розвитку довіри в системі міжособистісних відносин [9, 64]. Інші дослідники наголошують на значущості ціннісних орієнтацій в регуляції поведінки суб'єкта, вказуючи, що вони є основою оцінки навколишньої дійсності та детермінують схильність особистості до певної соціальної активності $[4,252]$. Г. Джонс та Дж. Джорж зазначають, що цінності забезпечують стандартами довіру, якої люди намагаються досягти під час взаємодії 3 іншими: індивіди переносять власну систему цінностей на партнерів в очікуванні відповідної поведінки останніх $[10,532]$.

Таким чином, проблема взаємозв'язку ціннісних орієнтацій та довіри особистості представлена в науковій літературі двома основними напрямами: осмисленням ролі ціннісних орієнтацій людини в регуляції довірчих відносин та розглядом збігу (схожості) ціннісних орієнтацій індивідів як необхідної умови виникнення довіри у взаєминах. Враховуючи відсутність аналогічних досліджень серед військовослужбовців, визначення взаємозв'язку між ціннісними орієнтаціями підлеглих і командирів та формуванням відносин довіри між ними $\epsilon$ достатньо актуальним.

Для розв'язання поставленого завдання було використано опитувальник для вивчення критеріїв довіри та недовіри 


\section{Питання психології}

особистості іншим людям А.Б. Купрейченко, С.П. Табхарової [4, 529-531] та методику вивчення ціннісних орієнтацій М. Рокіча [11]. В дослідженні прийняло участь 72 військовослужбовця-учасника Операції об'єднаних сил (Антитерористичної операціï) на території Донецької та Луганської областей (всіх категорій, крім строкової служби) військових частин різних видів Збройних Сил України віком від 19 до 46 років.

Опитувальник для вивчення критеріїв довіри та недовіри особистості іншим людям А.Б. Купрейченко та С.П. Табхарової містить 95 характеристик людини, що сприймається. Зазначені характеристики включають моральні, інтелектуальні, вольові, темпераментальні та характерологічні особистісні якості, особливості зовнішності та поведінки, соціально-групову належність, характер зв'язків, взаємодії, відносин з суб'єктом тощо. В якості ймовірного критерію довіри оцінюється ступінь збігу життєвих позицій. Для цього визначається значущість наявності у суб'єкта та іншої людини спільних, різних та протилежних за спрямованістю цілей, інтересів та світогляду. Респондентам було запропоновано оцінити за п'ятибальною шкалою (5 балів - повністю згоден, 4 скоріш згоден, 3 - важко відповісти, 2 скоріш не згоден, 1 - повністю не згоден) значущість кожної характеристики 3 представленого списку в якості критерію довіри по відношенню до командира (старшого начальника), якому вони довіряють в особливих умовах діяльності. При обробці результатів враховувались виставлені респондентами оцінки від 4 до 5 балів за кожну якість.

За результатами частотного аналізу отриманих відповідей найбільш значущими якостями довіри підлеглих командирові в уявленнях підлеглих виступають охайність $\quad(100 \%$ респондентів), активність (92\%), прагнення до стабільності (92\%), схоже сприйняття світу (88\%), неагресивність (85\%), розсудливість та серйозність $(85 \%)$, освіченість (85\%), сміливість (85\%), стриманість (85\%), ввічливість $(85 \%)$, розумність (85\%), організованість $(85 \%)$, надійність (85\%), авторитетність (81\%).

Вагомими критеріями довіри серед запропонованих респондентам варіантів виявились інтелектуальні якості командира (освіченість (85\%), розумність $(85 \%)$, винахідливість $(77 \%)), \quad$ моральні (справедливість (69\%)), вольові (сміливість (85\%), організованість (85\%), сила (73\%)).

Серед рис характеру високо значущими для довіри підлеглих $\epsilon$ стриманість командира (85\%), ввічливість (85\%), веселість (77\%), щирість (65\%), відкритість (62\%), допитливість (62\%).

Серед особистісно-професійних якостей важливими для довіри зазначено прагнення стабільності (92\%), надійність (85\%), розсудливість та серйозність $(85 \%)$, авторитетність (81\%), прорахунок всього (77\%), раціональність (73\%), незалежність $(73 \%)$, надання переваги компромісам (62\%), терпіння до недоліків інших (54\%), надання допомоги підлеглим (54\%).

Критеріями довіри зазначено також особливості зовнішності (охайність (100\%), одяг $(73 \%))$ та поведінки командира (активність (92\%), неагресивність (85\%)).

Особливої уваги заслуговують такі показники, як однакове сприйняття світу $(88 \%)$, схожість життєвих цілей $(73 \%)$ та широке коло інтересів (65\%). Зазначене свідчить про те, що серед критеріїв довіри командирові для військовослужбовців достатньо значущу роль відіграють його ціннісні орієнтації: інтереси, погляди, переконання, життєві цілі, ідеали, світогляд. Спостерігається перенесення респондентами власної системи цінностей на довіру як соціально-психологічне відношення: схожість у ціннісних орієнтаціях між підлеглими та керівником сприяє встановленню довіри у взаєминах.

Наступним кроком дослідження було вивчення ціннісно-мотиваційної сфери респондентів. Методика "Ціннісні орієнтації' М. Рокіча призначена дозволяє дослідити дві підгрупи цінностей:

- термінальні - це переконання в тому, що кінцева мета індивідуального існування варта того, щоб до неї прагнути 


\section{Питання психології}

(стимульний матеріал включає 18 цінностей);

- інструментальні - це переконання в тому, що певний образ дії чи властивість особистості має перевагу в будь-якій ситуації (стимульний матеріал також включає 18 цінностей).

Визначення таких підгруп відповідає традиційному поділу на бінарні системи: “цінності - цілі” (основоположні життєві цілі людини; виступають детермінантами поведінки та діяльності) та "цінності засоби” (розкривають способи реалізації цінностей-цілей).

Опитування проведено в два етапи. На першому етапі респондентам було запропоновано здійснити ранжування двох списків цінностей (по 18 позицій у кожному) в порядку значущості для себе. Найбільш значуща для респондента цінність ставилась на перше місце, найменш важлива - займала 18 місце у списку. Спочатку подавався набір термінальних цінностей, потім інструментальних.

На другому етапі було використано додаткову інструкцію: респондентам запропоновано здійснити ранжування цінностей в порядку значущості з позиції командира підрозділу, якому вони повністю довіряють (“Як, на Ваш погляд, розставив би цінності в порядку значущості командир підрозділу, якому б Ви повністю довіряли?”).

Визначення щільності зв'язків між проранжованими респондентами списками цінностей (між “Я - реальне" та "Командир, якому довіряють - ідеальне") здійснено 3 використанням коефіцієнту рангової кореляції Спірмена rs. Критичне значення коефіцієнту кореляції рангів Спірмена rs крит при $\mathrm{N}=18$ дорівнює 0,47 при $\mathrm{p} \leq 0,05$ та 0,60 при $\mathrm{p} \leq 0,01$. Зв'язок достовірний, якщо rs емп $\geq 0,05$, та тим більш достовірний, якщо rs емп $\geq 0,01$. Результати дослідження представлено в таблиці 1.

Таблиця 1

Значення коефіцієнту рангової кореляції Спірмена rs для термінальних та інструментальних цінностей

\begin{tabular}{|c|c|c|c|c|c|c|c|c|}
\hline \multirow{2}{*}{ n-респ } & \multicolumn{2}{|c|}{ коеф. Спірмена } & \multirow{2}{*}{ n-респ } & \multicolumn{2}{|c|}{ коеф. Спірмена } & \multirow{2}{*}{ С-респ } & \multicolumn{2}{|c|}{ коеф. Спірмена } \\
& rs терм. & rs інстр. & & rs терм. & rs інстр. & & rs терм. & rs інстр. \\
\hline 1 & 0,68 & 0,50 & 25 & 0,41 & 0,79 & 49 & 0,56 & 0,59 \\
\hline 2 & 0,41 & 0,39 & 26 & 0,64 & 0,45 & 50 & 0,54 & 0,44 \\
\hline 3 & 0,99 & 0,99 & 27 & 0,87 & 0,88 & 51 & 0,79 & 0,93 \\
\hline 4 & 0,54 & 0,69 & 28 & 0,67 & 0,96 & 52 & 0,73 & 0,41 \\
\hline 5 & 0,87 & 0,62 & 29 & 0,56 & 0,22 & 53 & 0,56 & 0,71 \\
\hline 6 & 0,99 & 0,95 & 30 & 0,42 & 0,67 & 54 & 0,47 & 0,37 \\
\hline 7 & 0,76 & 0,59 & 31 & 0,61 & 0,37 & 55 & 0,77 & 0,81 \\
\hline 8 & 0,46 & 0,40 & 32 & 0,55 & 0,46 & 56 & 0,64 & 0,53 \\
\hline 9 & 0,66 & 0,59 & 33 & 0,33 & 0,75 & 57 & 0,45 & 0,30 \\
\hline 10 & 0,39 & 0,92 & 34 & 0,50 & 0,40 & 58 & 0,50 & 0,89 \\
\hline 11 & 0,54 & 0,58 & 35 & 0,78 & 0,56 & 59 & 0,55 & 0,69 \\
\hline 12 & 0,61 & 0,49 & 36 & 0,73 & 0,48 & 60 & 0,69 & 0,56 \\
\hline 13 & 0,69 & 0,99 & 37 & 0,38 & 0,50 & 61 & 0,31 & 0,53 \\
\hline 14 & 0,98 & 0,99 & 38 & 0,69 & 0,38 & 62 & 0,47 & 0,35 \\
\hline 15 & 0,72 & 0,36 & 39 & 0,46 & 0,54 & 63 & 0,57 & 0,26 \\
\hline 16 & 0,59 & 0,69 & 40 & 0,45 & 0,43 & 64 & 0,84 & 0,75 \\
\hline 17 & 0,51 & 0,60 & 41 & 0,44 & 0,75 & 65 & 0,68 & 0,63 \\
\hline 18 & 0,30 & 0,52 & 42 & 0,81 & 0,97 & 66 & 0,54 & 0,50 \\
\hline 19 & 0,58 & 0,42 & 43 & 0,52 & 0,63 & 67 & 0,67 & 0,94 \\
\hline 20 & 0,52 & 0,80 & 44 & 0,68 & 0,71 & 68 & 0,43 & 0,99 \\
\hline 21 & 0,63 & 0,66 & 45 & 0,90 & 0,95 & 69 & 0,47 & 0,62 \\
\hline 22 & 0,74 & 0,45 & 46 & 0,51 & 0,98 & 70 & 0,55 & 0,54 \\
\hline 23 & 0,76 & 0,39 & 47 & 0,60 & 0,37 & 71 & 0,73 & 0,90 \\
\hline 24 & 0,45 & 0,77 & 48 & 0,53 & 0,64 & 72 & 0,75 & 0,89 \\
\hline
\end{tabular}

Примітка:

rs терм. - коефіцієнт рангової кореляції Спірмена для термінальних цінностей; rs інстр. - коефіцієнт рангової кореляції Спірмена для інструментальних цінностей. 


\section{Питання психології}

Отримані чисельні значення rs для термінальних та інструментальних цінностей свідчать про позитивний зв'язок між ціннісними орієнтаціями військовослужбовців (“Я - реальне”) та командирів, яким довіряють ("Командир, якому довіряють - ідеальне"): середнє значення коефіцієнта рангової кореляції Спірмена при $\mathrm{N}=18$ для термінальних цінностей $\mathrm{rs}$ cep $=0,61-$ кореляція статистично значуща (при $\mathrm{p} \leq 0,01$ ) та $\epsilon$ позитивною; для інструментальних цінностей - rs cep $=0,63-$ кореляція статистично значуща (при $\mathrm{p} \leq 0,01)$ та $\epsilon$ позитивною. Зазначене підтверджує висновок, наведений вище, про роль системи цінностей в якості регулятора відносин довіри: військовослужбовці схильні довіряти командирам, що мають схожі життєві цінності.

Для отримання узагальненої оцінки термінальних та інструментальних цінностей командира, якому довіряють, проведено обрахування середнього арифметичного значення групових результатів по кожній цінності окремо та їх ранжування в порядку зростання: цінності 3 найменшим усередненим рангом надано ранг 1 (найбільш значуща цінність), наступній цінності - ранг 2 і т. д. Цінність 3 рангом 18 вважаємо найменш значущою. Групова ієрархія оцінки респондентами ціннісних орієнтацій командира, якому довіряють, представлена в таблицях 2 та 3.

Таблиця 2

Групові результати оцінки термінальних цінностей командира, якому довіряють

\begin{tabular}{|c|c|c|c|}
\hline $\begin{array}{l}\text { № } \\
3 / \Pi\end{array}$ & Термінальні цінності & Ранг сер. зн. & Ранг \\
\hline 1. & Здоров’я (фізичне та психічне) & 4,93 & 1 \\
\hline 2. & $\begin{array}{l}\text { Життєва мудрість (зрілість суджень та здоровий глузд, які досягнуті } \\
\text { життєвим досвідом) }\end{array}$ & 5,90 & 2 \\
\hline 3. & $\begin{array}{l}\text { Впевненість в собі (внутрішня гармонія, свобода від внутрішніх протиріч, } \\
\text { сумнівів) }\end{array}$ & 6,89 & 3 \\
\hline 4. & Активне діяльне життя (повнота та емоційна насиченість життя) & 7,74 & 4 \\
\hline 5. & Цікава служба (робота, рід занять) & 8,42 & 5 \\
\hline 6. & Розвиток (робота над собою, постійне фізичне та духовне удосконалення) & 8,82 & 6 \\
\hline 7. & Щасливе сімейне життя & 9,29 & 7 \\
\hline 8. & Суспільне визнання (повага оточуючих, колективу, товаришів по службі) & 9,47 & 8 \\
\hline 9. & Наявність хороших та вірних друзів & 9,49 & 9 \\
\hline 10. & $\begin{array}{lcccc}\text { Продуктивне } & \text { життя (максимально } & \text { повне } & \text { використання } & \text { своїх } \\
\text { можливостей, сил та можливостей) } & & & \end{array}$ & 9,64 & 10 \\
\hline 11. & $\begin{array}{l}\text { Пізнання (можливість розширення своєї освіти, кругозору, загальної } \\
\text { культури, інтелектуальний розвиток) }\end{array}$ & 9,67 & 11 \\
\hline 12. & Любов (духовна та фізична близькість з коханою людиною) & 9,76 & 12 \\
\hline 13. & Матеріально забезпечене життя (відсутність матеріальних труднощів) & 10,17 & 13 \\
\hline 14. & $\begin{array}{l}\text { Щастя інших (благополуччя, розвиток та вдосконалення інших людей, } \\
\text { всього народу, людства в цілому) }\end{array}$ & 10,57 & 14 \\
\hline 15. & Свобода (самостійність, незалежність в судженнях та вчинках) & 11,24 & 15 \\
\hline 16. & $\begin{array}{l}\text { Красота природи та мистецтва (переживання прекрасного в природі та в } \\
\text { мистецтві) }\end{array}$ & 12,07 & 16 \\
\hline 17. & Творчість (можливість творчої діяльності) & 12,94 & 17 \\
\hline 18. & Розваги (приємне, необтяжливе проведення часу, відсутність обов’язків) & 12,97 & 18 \\
\hline
\end{tabular}

Таблиця 3

Групові результати оцінки інструментальних цінностей командира, якому довіряють

\begin{tabular}{|l|l|c|c|}
\hline № 3/п & \multicolumn{1}{|c|}{ Інструментальні цінності } & $\begin{array}{c}\text { Ранг сер. } \\
\text { зн. }\end{array}$ & Ранг \\
\hline 1. & Відповідальність (почуття обов’язку, вміння тримати своє слово) & 7,10 & 1 \\
\hline 2. & $\begin{array}{l}\text { Акуратність (охайність), вміння тримати речі в порядку, порядок у } \\
\text { справах }\end{array}$ & 7,85 & 2 \\
\hline 3. & Сміливість у відстоюванні своєї думки, поглядів & 8,14 & 3 \\
\hline 4. & Вихованість (гарні манери) & 8,29 & 4 \\
\hline
\end{tabular}




\section{Питання психології}

\begin{tabular}{|l|l|c|c|}
\hline 5. & Освіченість (широта знань, висока загальна культура) & 8,40 & 5 \\
\hline 6. & Самоконтроль (стриманість, самодисципліна) & 8,49 & 6 \\
\hline 7. & Виконавчість, старанність (дисциплінованість) & 8,51 & 7 \\
\hline 8. & Життерадісність (почуття гумору) & 8,57 & 8 \\
\hline 9. & $\begin{array}{l}\text { Тверда воля (уміння наполягти на своєму, не відступати перед } \\
\text { труднощами) }\end{array}$ & 8,71 & 9 \\
\hline 10. & $\begin{array}{l}\text { Раціоналізм (вміння розсудливо та логічно мислити, приймати } \\
\text { обдумані, виважені рішення) }\end{array}$ & 8,90 & 10 \\
\hline 11. & Незалежність (здатність діяти самостійно, рішуче) & 9,18 & 11 \\
\hline 12. & Чесність (правдивість, щирість) & 9,53 & 12 \\
\hline 13. & Ефективність у справах (працелюбність, продуктивність в роботі) & 10,07 & 13 \\
\hline 14. & Високі запроси (високі вимоги до життя та високі домагання) & 10,81 & 14 \\
\hline 15. & $\begin{array}{l}\text { Терпимість (до поглядів і думок інших, вміння прощати іншим їхні } \\
\text { помилки) }\end{array}$ & 11,04 & 15 \\
\hline 16. & $\begin{array}{l}\text { Широта поглядів (вміння зрозуміти чужу точку зору, поважати інші } \\
\text { смаки, звичаї, звички) }\end{array}$ & 11,19 & 16 \\
\hline 17. & Чуйність (піклування). & 12,74 & 17 \\
\hline 18. & Непримиренність до недоліків інших & 13,19 & 18 \\
\hline
\end{tabular}

Отримана в результаті дослідження індивідуальна ієрархія термінальних цінностей командира, якому довіряють, свідчить про те, що в уявленнях військовослужбовців найбільш значущими (ранги 1-6) для довіри $є$ індивідуальноособистісні цінності: здоров'я (фізичне та психічне), життєва мудрість (зрілість суджень та здоровий глузд, які досягнуті життєвим досвідом), впевненість в собі (внутрішня гармонія, свобода від внутрішніх протиріч, сумнівів). Достатньо високі оцінки отримали цінності професійної самореалізації: цікава служба (робота, рід занять); активне діяльне життя (повнота та емоційна насиченість життя); розвиток (робота над собою, постійне фізичне та духовне удосконалення).

В ієрархії інструментальних цінностей командира, якому довіряють підлеглі, найбільш значущими $є$ цінності професійної діяльності: відповідальність (почуття обов'язку, вміння тримати своє слово); вміння тримати речі в порядку, порядок у справах. Високі ранги отримали цінності самоствердження (сміливість у відстоюванні своєї думки, поглядів), цінності міжособистісного спілкування (вихованість, гарні манери) та інтелектуальні цінності: освіченість (широта знань, висока загальна культура); самоконтроль (стриманість, самодисципліна).

Таким чином, можемо констатувати, що в системі термінальних цінностей командира, якому довіряють, в уявленнях військовослужбовців значущим $\epsilon$ професійний блок. Серед інструментальних

цінностей переважають цінності

професійної самореалізації. Зазначене свідчить про конгруентність між цінностями-засобами та цінностямицілями: головні життєві пріоритети достатньо узгоджені зі способами їх реалізації. Також заслуговує на увагу той факт, що обрані респондентами основні якості командира (в межах 85-100\%), якому довіряють, практично тотожні 3 його найбільш вагомими (ранги 1-6) інструментальними цінностями.

Загалом слід відмітити високу значущість у формуванні довіри військовослужбовців саме цінностей військово-професійної діяльності в загальній системі цінностей командира. Зазначена тенденція обумовлена приналежністю респондентів до певної соціальної групи - категорії військових. Безумовно, життєві цінності командира визначають його поведінку, стиль управління підлеглими. Військовослужбовці схильні довіряти розумним, розсудливим та досвідченим командирам, які при прийнятті рішень, виконанні завдань керуються принципами об'єктивності, раціональності та доцільності. Відданість військовій справі, відповідальність та постійне професійне удосконалення керівника підвищують довіру підлеглих.

\section{Висновки.}

1. Аналіз отриманих емпіричних даних свідчить про наявність позитивного зв'язку між ціннісними орієнтаціями військовослужбовців і командирів та 


\section{Питання психології}

формуванням відносин довіри між ними: схожість у ціннісних орієнтаціях між підлеглими та керівником сприяє встановленню довіри у взаєминах. Серед найбільш значущих якостей командира, якому довіряють підлеглі, показники збігу ціннісних орієнтацій відіграють суттєву роль.

2. В отриманій за результатами дослідження індивідуальній ієрархії цінностей командира, якому довіряють, у термінальній підгрупі переважають цінності, пов'язані із професійною діяльністю, в інструментальній - цінності професійної самореалізації. Зазначена тенденція обумовлена приналежністю респондентів до певної соціальної групи та значущістю для них у формуванні довірчих відносин цінностей професійної діяльності. Обрані респондентами основні якості командира, якому довіряють, практично тотожні 3 його найбільш вагомими інструментальними цінностями.

Перспективи

подальших досліджень вбачаємо у створенні та апробації анкети, що оцінює рівень довіри підлеглих командиру (начальнику) в особливих умовах діяльності.

\section{Список використаних джерел}

1. Matsumoto D. The Cambridge dictionary of psychology. Cambridge University Press, 2009.

2. Філософський енциклопедичний словник / ред-упоряд. В. І. Шинкарчук. Київ : Абрис, 2002. $742 \mathrm{c}$.

3. Обозов Н. Н. Психология межличностных отношений. Киев : Лыбидь, 1990. 192 с.

4. Купрейченко А. Б. Психология доверия и недоверия. Москва : Институт психологии РАН, 2008. $571 \mathrm{c}$.

5. Позняков В.П. Психологические отношения человека: современное состояние исследований и перспективы развития концепции. Социальная и экономическая психология. Москва. 2017. № 2, том 2. С. 6-30. $424 \mathrm{c}$.

6. Психологічна енциклопедія / автор-упорядник О. М. Степанов. Київ : Академвидав, 2006.

7. Гозман Л. Я. Психология эмоциональных отношений : монография. Москва : МГУ, 1987. $76 \mathrm{c}$.

8. Алексеева А. Ю. Основные элементы и структура межличностного доверия. Социологический журнал. Москва, 2009. №3. С. 22-41.

9. Балуцкий И. В. Особенности проявления доверия в статусных межличностных отношениях : дис. на соиск. уч ст. канд. псих наук : 19.00.05. Ростов-на-Дону, 2002. 160 с.

10. Gareth R. Jones, Jennifer M. George. The Experience and Evolution of Trust: Implications for Cooperation and Teamwork. The Academy of Management Review. Vol. 23. No. 3 (Jul., 1998), PP. 531546. URL: http://www.jstor.org/stable/259293 (дата звернення: 05.08.2019).

11. Практическая психодиагностика / ред. Д. Я. Райгородский. Самара : ИД «БАХРАХ-М», 2000. $672 \mathrm{c}$.

\section{References}

1. Matsumoto D. (2009). The Cambridge dictionary of psychology. Cambridge University Press. (in English).

2. Shynkarchuk, V. I. (2002). Filosofskyi entsyklopedychnyi slovnyk [Encyclopedic Dictionary of Philosophy]. Kyiv : Abrys. (in Ukrainian).

3. Obozov, N. N. (1990). Psihologija mezhlichnostnyh otnoshenij [Psychology of interpersonal relationships]. Kiev : Lybid'. (in Russian).

4. Kuprejchenko, A. B. (2008). Psihologija doverija i nedoverija [Psychology of trust and distrust]. Moskva : Institut psihologii RAN. (in Russian).

5. Poznjakov, V. P. (2017). Psihologicheskie otnoshenija cheloveka: sovremennoe sostojanie issledovanij i perspektivy razvitija koncepcii [Psychological relations of a person: the present status of theresearchand prospects of the concept's development]. Social'naja i jekonomicheskaja psihologija. Moskva. 2(2), 6-30. (in Russian).

6. Stepanov, O. M. (2006). Psykholohichna entsyklopediia [Dictionary of psychology]. Kyiv : Akademvydav. (in Ukrainian).

7. Gozman, L. Ja. (1987). Psihologija jemocional'nyh otnoshenij [Psychology of emotional relationships]. Moskva : MGU. (in Russian).

8. Alekseeva, A. Ju. (2009). Osnovnye jelementy i struktura mezhlichnostnogo doverija [Main elements and structure of interpersonal trust]. Sociologicheskij zhurnal. Moskva, 3, 22-41. (in Russian). 


\title{
Питання психології
}

9. Baluckij, I. V. (2002). Osobennosti projavlenija doverija $\mathrm{v}$ statusnyh mezhlichnostnyh otnoshenijah [Features of the manifestation of trust in status interpersonal relationships] (Abstract of PhD dissertation). Rostov-na-Donu. (in Russian).

10. Gareth R. Jones, \& Jennifer M. George. (1998). The Experience and Evolution of Trust: Implications for Cooperation and Teamwork. The Academy of Management Review. 23(3), 531-546. Retrieved from http://www.jstor.org/stable/259293. (in English).

11. Rajgorodskij, D. Ja. (2000). Prakticheskaja psihodiagnostika. [Practical Psychodiagnostics]. Samara : «BAHRAH-M». (in Russian).

\author{
Резюме \\ Стасюк В. доктор психологических наук, профессор, \\ кафедра морально-психологического обеспечения \\ деятельности войск (сил), Национальныгй университет \\ обороны Украины имени Ивана Черняховского \\ Лисенко Д. адъюнкт, кафедра морально-психологического \\ обеспечения деятельности войск (сил), Национальный \\ университет обороны Украины имени Ивана Черняховского \\ КОМАНДИРУ В ОСОБЫХ УСЛОВИЯХ ЕЯТЕЛЬНОСТИ
}

ЦЕННОСТНЫЕ ОРИЕНТАЦИИ В СТРУКТУРЕ ДОВЕРИЯ ВОЕННОСЛУЖАЩИХ К

В статье рассмотрены соииально-психологические особенности взаимосвязи иенностных ориентаций и доверия личности; проанализирована взаимосвязь между ценностными ориентациями военнослужащих и командиров и формированием отномений доверия между ними; получено индивидуальную иерархию ценностей командира, которому доверяют.

Ключевые слова: ценности; ценностные ориентации; терминальные ценности; инструментальные ценности; межличностные отномения; психологическое отночение; доверие; доверительные отношения.

\author{
Summary \\ Stasiyk $\boldsymbol{V}$. doctor of sciences (Psychology), professor, \\ Department of Moral and Psychological Support of the \\ Troops Activity (Forces), National Defense University of \\ Ukraine named after Ivan Chernjakhovskiy \\ Lysenko D. adjunct, Department of Moral and Psychological \\ Support of the Troops Activity (Forces), National Defense
}

University of Ukraine named after Ivan Chernjakhovskiy.

\section{PERSONNEL TO THE COMMANDER IN SPECIAL CONDITIONS OF ACTIVITY}

The article deals with the social and psychological peculiarities of the relationship of value orientations and personal trust. The problem of the relationship of value orientations and personal trust is presented in the scientific literature in two main directions: understanding the role of human value orientations in the regulation of trust relations and consideration of the coincidence (similarity) of value orientations of individuals as a necessary condition for the emergence of trust in relationships.

The empirical research of the relationship of the value orientations of military personnel and commanders, the formation of trust relationships between them have been conducted.

The main qualities of a commander, who is trusted by subordinates, are established, elucidated the coincidence indicators role of value orientations. The presence of a positive relationship between indicators are the similarity in value orientations between subordinates and the leaders' help in order to establish trust in relationships.

The individual hierarchy of values of the commander, who is trusted, have been defined. It was established that, the values associated with professional activity prevail in the terminal subgroup, the values of professional self-realization prevail in the instrumental one. This tendency of respondents' belonging to a certain social group and significance in the formation of trustful relations between the values of professional activity was defined. The main qualities of the trusted commander, chosen by the respondents, are almost identical with his her most significant instrumental values.

The prospects for further research is creation and testing of a questionnaire, which assesses the level of trust of subordinates to the commander leader in special conditions of activity.

Keywords: values; value orientations; terminal values; instrumental values; interpersonal relationship; psychological attitude; trust; trust-based relations. 